\title{
The Effect of Eruption Level and Angulation of Third Molars on Interdental Root Proximity: A Case-Control Study
}

\author{
Maria-Anna Loukideli, Alexandra Tsami, Eudoxie Pepelassi* and Ioannis Vrotsos \\ Department of Periodontology, School of Dentistry, National and Kapodistrian University of Athens, Athens, Greece
}

*Corresponding author: Eudoxie Pepelassi, Department of Periodontology, School of Dentistry, National and Kapodistrian University of Athens, 11527 Athens, Greece; Tel: +0030 2107461223, 2107461203; E-mail: epepela@dent.uoa.gr

Received: February 19, 2019; Accepted: February 27, 2019; Published: March 05, 2019;

\begin{abstract}
This study was designed to assess the possible relationship between the level of eruption or impaction status and angulation of third molars (TMs) and the interdental root proximity (RP) in this quadrant, in adults with healthy periodontium and in patients with history of periodontitis. Root proximity was studied in the interdental spaces of 250 patients with periodontitis and 80 subjects with healthy and intact periodontium. Linear measurements were performed in digital radiographs. Root proximity was detected when the distance at the closest proximity level between the roots of adjacent teeth was $<0.8 \mathrm{~mm}$. Eruption level was classified as full or partial, based on occlusal plane. Impaction status was assessed as semi or complete, based on coverage by soft tissues or alveolar bone. The Z-test, $X^{2}$, Fisher's exact test and Mann-Whitney test were used for the statistical analysis. In total, 718 TMs and 4,308 interdental spaces were studied in 330 subjects. In subjects with healthy periodontium, the angulation of mandibular TMs statistically significantly influenced the presence of root proximity in the interdental space between first and second molars. In periodontitis subjects, TM angulation statistically significantly affected the presence of root proximity in the interdental space between first and second molars in the maxillary left and mandibular right quadrants as well as in the interdental space between the mandibular right premolars. The eruption level or impaction status of TMs statistically significantly affected the presence of root proximity only between the first and second mandibular right molars both for subjects with healthy periodontium and for periodontitis patients. Within its limits, this study found that the angulation and eruption level or impaction status of third molars seem to be related to root proximity among the adjacent teeth, especially between lower first and second molars, irrespective of the presence or absence of periodontitis.
\end{abstract}

Key words: Angulation, Digital Radiography, Eruption, Interdental Root Proximity, Periodontitis, Periodontal Health, Third Molar, Third Molar Positioning

\section{Introduction}

Third molars (TMs) are the last in the tooth eruption sequence. The calcification of the TMs starts at 7 to 10 years of age and the calcification of the TM crown is completed at 12 to 16 years of age. Their eruption begins at the age of 17 to 21 years. The time of their formation varies widely due mainly to variations in crown and root morphology. TMs have the highest rate of development abnormalities. More than $20 \%$ of humans fail to develop at least one TM $[1,2]$, whereas TM agenesis accounts for about $75 \%$ of all affected teeth [3]. They are often impacted, with higher impaction rate for the mandible than the maxilla. The incidence of TM impaction may increase up to $50 \%$ in patients who have been orthodontically treated [4].

TMs are associated with a reduced amount of growth and with a more downward than forward direction of tooth eruption. The eruption status of TMs depends on the dimensions of the retromolar area. If there is sufficient space in the retromolar area, the TMs may completely or partially erupt depending on their axial positioning. The full or semi impaction of TM is often the result of a tooth/tissue disharmony or crowding. The retromolar area is the only significant variable associated with lateral asymmetry in the eruption or impact status of TMs. Hattab and Alhaija [5] assessed radiographically 213 mandibular TMs in 134 subjects and found that there was a strong positive relationship between the frequency of TM impaction and the degree of TM angulation and that the former was inversely associated with the retromolar area width. Inadequate retromolar area space was the most significant factor associated with TM impaction. Most impacted TMs had retromolar space/crown ratios of less than 1.

The position or angulation of TMs might change, mainly when they are visible clinically or partially impacted [6]. Such changes might occur even after completion of the jaw growth and TMs might erupt to the occlusal plane, yet at one third of vertically positioned impacted teeth during the third decade of life [7-9] or especially by the time the individual reached 24 [10] or 26 years of age [11]. It still remains unanswered whether the changes in position or angulation influence the root proximity of adjacent teeth, especially the interdental spaces between second and first molars. The extraction of impacted third molars (ITMs) seems a rather prophylactic surgical procedure for young adults, especially for orthodontic patients. The ideal orthodontic treatment plan should include rationale and 
recommendations for TMs extractions, whenever indicated [12, 13]. The purpose of the present study was to evaluate the relationship between the level of eruption or impaction status and angulation of TMs and the root proximity (RP), in adult individuals with healthy periodontium and in adult patients with history of periodontitis.

\section{Materials and Methods}

\section{Study sample}

The study sample was taken from 330 full mouth sets of conventional periapical radiographs belonging to 330 patients originating from the pool of the patients of the Department of Periodontology, School of Dentistry, National and Kapodistrian University of Athens and from private dental practices. Each subject signed an informed consent form prior to enrollment to the study. The study protocol was approved by the Ethics and Research Committee of the School of Dentistry, National and Kapodistrian University of Athens. Two groups of subjects were studied. Specifically, there were 80 subjects ( 31 men and 49 women; mean age $27.5 \pm 0.6$ years) with healthy and intact periodontium, who were classified in group A (control group) and 250 subjects ( 82 men and 168 women; mean age $44 \pm 0.5$ years) with moderate to advanced periodontitis, who were classified in group B (test group). The diagnosis of periodontitis was based on the clinical attachment level measurements [14]. The patient inclusion criteria were: presence of at least 28 teeth, presence of 26 interdental spaces, presence of full-mouth periapical radiographs and absence of third molar extraction and/or surgical intervention in the posterior jaw sextants for the last 5 years. The patient exclusion criteria were: orthodontic treatment, periodontal treatment (either non-surgical or surgical) for the last six months, medical condition or medication affecting the periodontium and presence of supernumerary or impacted teeth, except for third molars.

All radiographs were taken with the long-cone paralleling technique with the central beam directed to the alveolar crest and then assessed for sings of RP between adjacent teeth. Radiographic images with possible RP were transformed into digital images, to a resolution of 300 dpi with 8 bits of gray level resolution per pixel. RP was defined as an interdental distance of less than $0.8 \mathrm{~mm}(<0.8 \mathrm{~mm})$ at the closest proximity level [15-17], as assessed from the digitized image in pixels (10 pixels $=1 \mathrm{~mm})$. All interdental spaces were evaluated for RP $\left(M_{2}-M_{1}\right.$ : interdental space between second and first molar, $M_{1}-$ $\mathrm{P}_{2}$ : interdental space between first molar and second premolar, $\mathrm{P}_{2}-\mathrm{P}_{1}$ : interdental space between second and first premolar, $\mathrm{P}_{1}$-C: interdental space between first premolar and canine, $\mathrm{C}_{2} \mathrm{I}_{2}$ : interdental space between canine and lateral incisor, $\mathrm{I}_{2}-\mathrm{I}_{1}$ : interdental space between lateral and central incisor).

In total, 718 TMs were studied, of which 238 belonged to group A and 480 to group B. For each TM, the level of eruption or status of impaction and the angulation were recorded, as assessed from conventional periapical radiographs. Erupted TMs were classified in relation to the level of eruption into fully erupted (FETMs), when erupted to the level or above the occlusal plane, and partially erupted (PETMs), when erupted below the occlusal plane. Impacted TMs were classified in relation to the status of impaction into semi impacted
(SITMs), when partially covered by soft tissues or alveolar bone, and completely impacted (CITMs), when completely covered by soft tissues and alveolar bone $[18,19]$. TM angulation was assessed relative to the long axis of the adjacent second molar [20], specifically the angle (in angle degrees) formed by the long axis of the TM and the long axis of the adjacent second molar [6] was recorded. All radiographic measurements, linear or angular, were performed by one investigator (A-M. L.) with the Emago/Advanced dental image archiving software (3 EXE, Oral Diagnostic System, Amsterdam, The Nederlands). Each measurement was assessed twice (3 weeks apart) and the average value was taken for further analyses. The intra-examiner agreement was very high, with the weighted $\mathrm{k}$ between 0.92 and 0.94 .

\section{Statistical methods}

Descriptive statistics for eruption status and angulation of TM were calculated as mean \pm standard deviation (SD) for both groups (A and $\mathrm{B}$ ). The Z-test was used for the comparison of two percentages on the incidence of RP per group, jaw or quadrant. The Z-test was used for the comparison of the two percentages of TM quadrant distribution between the two subject groups ( $\mathrm{A}$ and $\mathrm{B}$ ). The $\mathrm{X}^{2}$ was used for the comparison of the distribution of TMs between the two subject groups and between interdental spaces with or without RPs. Fisher's exact test was performed for the comparison of the presence of RP in the interdental spaces in relation to the TM eruption level or impaction status. Mann-Whitney test was performed for the comparison of the mean angulation values between interdental spaces with or without RP for both groups (A and B). The level of statistical significance was set at $5 \%(\mathrm{p}=0.05)$. Statistical analysis was conducted using the STATA 0.9 software package.

\section{Results}

In total, 718 TMs were studied, of which 238 belonged to group A subjects and 480 to group B subjects. TM distribution did not statistically significantly differ between subject groups (A and B) both in total $\left(\mathrm{X}^{2}=5.79\right.$ and $\left.\mathrm{p}>0.05\right)$ and in quadrants (upper right-URTMs: $\mathrm{Z}=1.775, \mathrm{p}=0.076$, upper left-ULTMs: $\mathrm{Z}=1.091, \mathrm{p}=0.275$, lower leftLLTMs: $Z=1.421, \mathrm{p}=0.151$, lower right-LRTMs: $\mathrm{Z}=1.312, \mathrm{p}=0.192$ ) (Table 1). The quadrant distribution of TMs in response to eruption level, impaction status and angulation for groups A and B is presented in tables 2 and 3, respectively. For group A, mean TM angulation was greatest for LRTMs $\left(21.6^{\circ} \pm 23.7^{\circ}\right)$ and least for URTMs and ULTMs $\left(11.4^{\circ} \pm 8.6^{\circ}\right.$ and $11.7^{\circ} \pm 8.7^{\circ}$, respectively) (Table 2). For group B, mean TM angulation was greatest for LRTMs $\left(16.2^{\circ} \pm 16.7^{\circ}\right)$ and least for URTMs $\left(11.4^{\circ} \pm 8.8^{\circ}\right)$ (Table 3$)$.

In total, 4,308 interdental spaces were studied for RP, of which 1,428 belonged to group A subjects and 2,880 to group B subjects. RP was detected in 505 interdental spaces (11.72\%), specifically in 167 group A interdental spaces (11.69\%) and in 338 group B spaces (11.73\%). The distribution of RP did not statistically significantly differ between the two subject groups (A and B) both in total $(\mathrm{Z}=0.038, \mathrm{p}$ $=0.976$ ) and in quadrants (URTMs: $Z=0.007, p=0.99$, ULTMs: $Z=$ $0.916, \mathrm{p}=0.93$, LLTMs: $\mathrm{Z}=0.364, \mathrm{p}=0.72$, LRTMs: $\mathrm{Z}=0.791, \mathrm{p}=$ 0.43) (Figure 1).

For group A, the highest frequency of RP for all four quadrants was found for the $I_{2}-I_{1}$ interdental space. In descending order, the 
second most frequent interdental space presenting RP was the $M_{2}-M_{1}$ space for both maxillary quadrants, the P1-C space for the mandibular left quadrant and the $\mathrm{M}_{2}-\mathrm{M}_{1}, \mathrm{P} 1-\mathrm{C}$ spaces for the mandibular right quadrant (Figure 2). For group B, the highest frequency of RP for both maxillary quadrants was found for the $\mathrm{M}_{2}-\mathrm{M}_{1}$ interdental space, whereas the highest frequency of RP for both mandibular quadrants was found for the $I_{2}-I_{1}$ interdental space. In descending order, the second most frequent interdental space presenting RP was the $\mathrm{P}_{2}$ $\mathrm{P}_{1}$ space for the maxillary right quadrant, the M1-P2 space for the maxillary left quadrant and the $\mathrm{M}_{2}-\mathrm{M}_{1}$ space for both mandibular quadrants (Figure 3).

Table 1. Comparison of the distribution of third molars in total and in quadrants between the subject groups (A and B).

\begin{tabular}{|c|c|c|c|c|c|}
\hline Groups & $\begin{array}{c}\text { URTMs Number } \\
(\%)\end{array}$ & $\begin{array}{c}\text { ULTMs Number } \\
(\%)\end{array}$ & $\begin{array}{c}\text { LLTMs Number } \\
(\%)\end{array}$ & $\begin{array}{c}\text { LRTMs Number } \\
(\%)\end{array}$ & $\begin{array}{c}\text { TMs in total Number } \\
(\%)\end{array}$ \\
\hline Total & $\begin{array}{c}171 \\
(23.82 \%\end{array}$ & $\begin{array}{c}164 \\
(22.84)\end{array}$ & $\begin{array}{c}199 \\
(27.71 \%)\end{array}$ & $\begin{array}{c}184 \\
(25.63 \%)\end{array}$ & $\begin{array}{c}718 \\
(100.00 \%)\end{array}$ \\
\hline Group A & $\begin{array}{c}66 \\
(9.19 \%)\end{array}$ & $\begin{array}{c}60 \\
(8.36 \%)\end{array}$ & $\begin{array}{c}58 \\
(8.07 \%)\end{array}$ & $\begin{array}{c}54 \\
(7.52 \%)\end{array}$ & $\begin{array}{c}238 \\
(33.14 \%)\end{array}$ \\
\hline Group B & $\begin{array}{c}105 \\
(14.63 \%)\end{array}$ & $\begin{array}{c}104 \\
(14.48 \%)\end{array}$ & $\begin{array}{c}141 \\
(19.64 \%)\end{array}$ & $\begin{array}{c}130 \\
(18.11 \%)\end{array}$ & $\begin{array}{c}480 \\
(66.86 \%)\end{array}$ \\
\hline Z-testa & 1.775 & 1.091 & 1.421 & 1.312 & 8.378 \\
\hline p-value & 0.076 & 0.275 & 0.151 & 0.192 & 0.00 \\
\hline
\end{tabular}

TMs: third molars, URTMs: upper right third molars, ULTMs: upper left third molars, LLTMs: lower left third molars, LRTMs: lower right third molars.

a:Comparison of the two percentages of TM quadrant distribution between the groups.

Table 2. Quadrant distribution of third molars (URTMs, ULTMs, LLTMs, LRTMs) in response to eruption level (FETMs, PETMs) or impaction status (SITMs, CITMs) and angulation for group A.

\begin{tabular}{|c|c|c|c|c|c|c|}
\hline \multicolumn{2}{|c|}{ Parameters } & \multirow{2}{*}{$\begin{array}{c}\text { FETMs } \\
(147)\end{array}$} & \multirow{2}{*}{$\begin{array}{c}\text { PETMs } \\
(30) \\
6 \\
(7.5 \%)\end{array}$} & \multirow{2}{*}{$\begin{array}{c}\text { SITMs } \\
(50) \\
13 \\
(16.25 \%)\end{array}$} & \multirow{2}{*}{$\begin{array}{c}\text { CITMs } \\
(11) \\
\begin{array}{c}1 \\
(1.25 \%)\end{array}\end{array}$} & \multirow{2}{*}{$\begin{array}{c}\begin{array}{c}\text { Total } \\
(238)\end{array} \\
66 \\
(82.5 \%)\end{array}$} \\
\hline \multirow{2}{*}{ URTMS } & $\begin{array}{c}\text { Number } \\
(\%)\end{array}$ & & & & & \\
\hline & $\begin{array}{c}\text { Angle }\left(^{\circ}\right) \\
\mathbf{x} \pm S D^{*}\end{array}$ & $10.2 \pm 6.6$ & $20.8 \pm 16.3$ & $12.5 \pm 8.0$ & $4 * *$ & $11.4 \pm 8.6$ \\
\hline \multirow{2}{*}{ ULTMS } & $\begin{array}{c}\text { Number } \\
(\%)\end{array}$ & $\begin{array}{c}37 \\
(46.25 \%)\end{array}$ & $\begin{array}{c}8 \\
(10 \%)\end{array}$ & $\begin{array}{c}10 \\
(12.5 \%)\end{array}$ & $\begin{array}{c}5 \\
(6.25 \%)\end{array}$ & $\begin{array}{c}60 \\
(75.0 \%)\end{array}$ \\
\hline & $\begin{array}{c}\text { Angle }\left(^{\circ}\right) \\
\mathbf{x} \pm S D^{*}\end{array}$ & $9.5 \pm 5.1$ & $9.3 \pm 5.8$ & $15.1 \pm 13.0$ & $24.6 \pm 11.7$ & $11.7 \pm 8.7$ \\
\hline \multirow{2}{*}{ LLTMS } & $\begin{array}{c}\text { Number } \\
(\%)\end{array}$ & $\begin{array}{c}33 \\
(41.25 \%)\end{array}$ & $\begin{array}{c}11 \\
(13.75 \%)\end{array}$ & $\begin{array}{c}11 \\
(13.75 \%)\end{array}$ & $\begin{array}{c}3 \\
(3.75 \%)\end{array}$ & $\begin{array}{c}58 \\
(72.5 \%)\end{array}$ \\
\hline & $\begin{array}{c}\left.\text { Angle ( }{ }^{\circ}\right) \\
\mathbf{x} \pm S D^{*}\end{array}$ & $6.6 \pm 4.9$ & $9.1 \pm 8.0$ & $36.9 \pm 2.3$ & $46 \pm 40.1$ & $14.9 \pm 18.8$ \\
\hline \multirow{2}{*}{ LRTMS } & $\begin{array}{c}\text { Number } \\
(\%)\end{array}$ & $\begin{array}{c}31 \\
(38.75 \%)\end{array}$ & $\begin{array}{c}5 \\
(6.25 \%)\end{array}$ & $\begin{array}{c}16 \\
(20.0 \%)\end{array}$ & $\begin{array}{c}2 \\
(2.5 \%)\end{array}$ & $\begin{array}{c}54 \\
(67.5 \%)\end{array}$ \\
\hline & $\begin{array}{c}\left.\text { Angle ( }{ }^{\circ}\right) \\
\mathbf{x} \pm S D^{*}\end{array}$ & $8.1 \pm 5.9$ & $16.8 \pm 13.4$ & $45.3 \pm 26.1$ & $52 \pm 33.9$ & $21.6 \pm 23.7$ \\
\hline \multicolumn{7}{|c|}{$\begin{array}{l}\text { URTMs: upper right third } \\
\text { lower right third molars, } \\
=\text { semi impacted third mo } \\
* \text { mean value } \pm \text { standard } d \\
* * \text { only one observation }\end{array}$} \\
\hline
\end{tabular}


Table 3. Quadrant distribution of third molars (URTMs, ULTMs, LLTMs, LRTMs) in response to eruption level (FETMs, PETMs) or impaction status (SITMs, CITMs) and angulation for group B.

\begin{tabular}{|c|c|c|c|c|c|c|}
\hline \multicolumn{2}{|c|}{ Parameters } & \multirow{2}{*}{$\begin{array}{c}\text { FETMs a } \\
(373) \\
77 \\
(30.8 \%)\end{array}$} & \multirow{2}{*}{$\begin{array}{c}\text { PETMs a } \\
(34) \\
6 \\
(2.4 \%)\end{array}$} & \multirow{2}{*}{$\begin{array}{c}\text { SITMs a } \\
(58) \\
18 \\
(7.2 \%)\end{array}$} & \multirow{2}{*}{$\begin{array}{c}\begin{array}{c}\text { CITMs a } \\
(15)\end{array} \\
4 \\
(1.6 \%)\end{array}$} & \multirow{2}{*}{$\begin{array}{c}\begin{array}{c}\text { Total } \\
(480)\end{array} \\
\begin{array}{c}105 \\
(42 \%)\end{array}\end{array}$} \\
\hline URTMs & $\begin{array}{c}\text { Number } \\
(\%)\end{array}$ & & & & & \\
\hline & $\begin{array}{c}\left.\text { Angle ( }{ }^{\circ}\right) \\
\mathbf{x} \pm S D^{*}\end{array}$ & $8.2 \pm 4.8$ & $12.7 \pm 7.5$ & $21.6 \pm 10.9$ & $29.0 \pm 7.5$ & $11.6 \pm 8.8$ \\
\hline \multirow{2}{*}{ ULTMs } & $\begin{array}{c}\text { Number } \\
(\%)\end{array}$ & $\begin{array}{c}80 \\
(32 \%)\end{array}$ & $\begin{array}{c}8 \\
(3.2 \%)\end{array}$ & $\begin{array}{c}11 \\
(4.4 \%)\end{array}$ & $\begin{array}{c}5 \\
(2 \%)\end{array}$ & $\begin{array}{c}104 \\
(41.6 \%)\end{array}$ \\
\hline & $\begin{array}{c}\text { Angle }\left(^{\circ}\right) \\
\mathbf{x} \pm S D^{*}\end{array}$ & $8.3 \pm 4.6$ & $13.4 \pm 3.9$ & $30.3 \pm 17.7$ & $35.8 \pm 11.7$ & $12.3 \pm 11.3$ \\
\hline \multirow{2}{*}{ LLTMS } & $\begin{array}{c}\text { Number } \\
(\%)\end{array}$ & $\begin{array}{c}112 \\
(44.8 \%)\end{array}$ & $\begin{array}{c}13 \\
(5.2 \%)\end{array}$ & $\begin{array}{c}13 \\
(5.2 \%)\end{array}$ & $\begin{array}{c}3 \\
(1.2 \%)\end{array}$ & $\begin{array}{c}141 \\
(56.4 \%)\end{array}$ \\
\hline & $\begin{array}{c}\left.\text { Angle ( }{ }^{\circ}\right) \\
\mathbf{x} \pm S D^{*}\end{array}$ & $10.2 \pm 6.2$ & $\begin{array}{c}18.2 \pm \\
11.5\end{array}$ & $38.3 \pm 14.9$ & $37.7 \pm 31.9$ & $14.1 \pm 12.5$ \\
\hline \multirow{2}{*}{ LRTMS } & $\begin{array}{c}\text { Number } \\
(\%)\end{array}$ & $\begin{array}{c}104 \\
(41.6 \%)\end{array}$ & $\begin{array}{c}7 \\
(2.8 \%)\end{array}$ & $\begin{array}{c}16 \\
(6.4 \%)\end{array}$ & $\begin{array}{c}3 \\
(1.2 \%)\end{array}$ & $\begin{array}{c}130 \\
(52 \%)\end{array}$ \\
\hline & $\begin{array}{c}\left.\text { Angle ( }{ }^{\circ}\right) \\
\mathbf{x} \pm S D^{*}\end{array}$ & $10.7 \pm 6.9$ & $\begin{array}{c}22.4 \pm \\
23.5\end{array}$ & $37.5 \pm 19.7$ & $77.3 \pm 10.7$ & $16.2 \pm 16.7$ \\
\hline
\end{tabular}

URTMs: upper right third molars, ULTMs: upper left third molars, LLTMs: lower left third molars, LRTMs: lower right third molars, FETMs: fully erupted third molars, PETMs: partially erupted third molars, SITMs = semi impacted third molars, CITMs = completely impacted third molars.

$*$ mean value \pm standard deviation

** only one observation

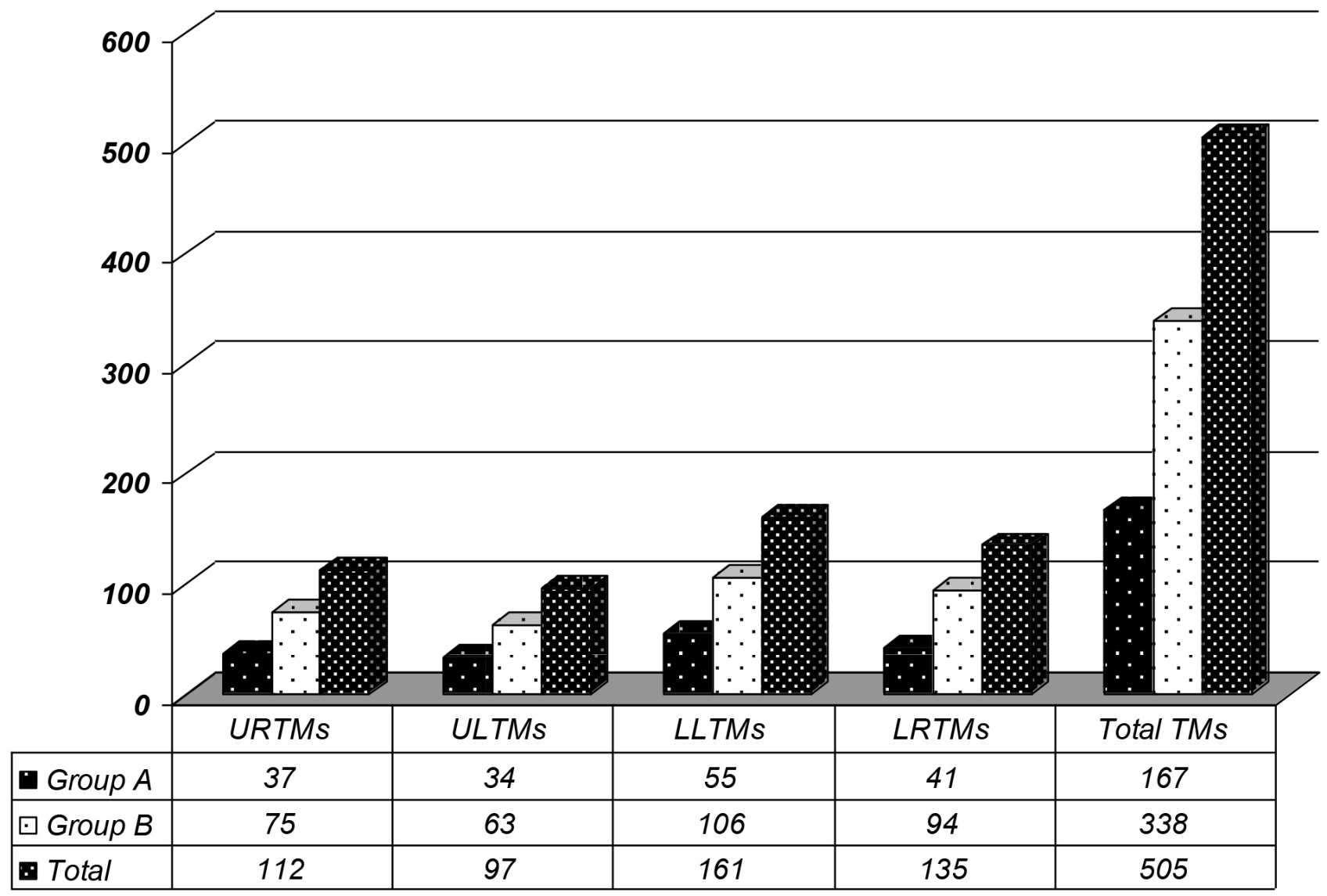

Figure 1. Distribution of root proximities (RP) in quadrants by subject group (A and B). 


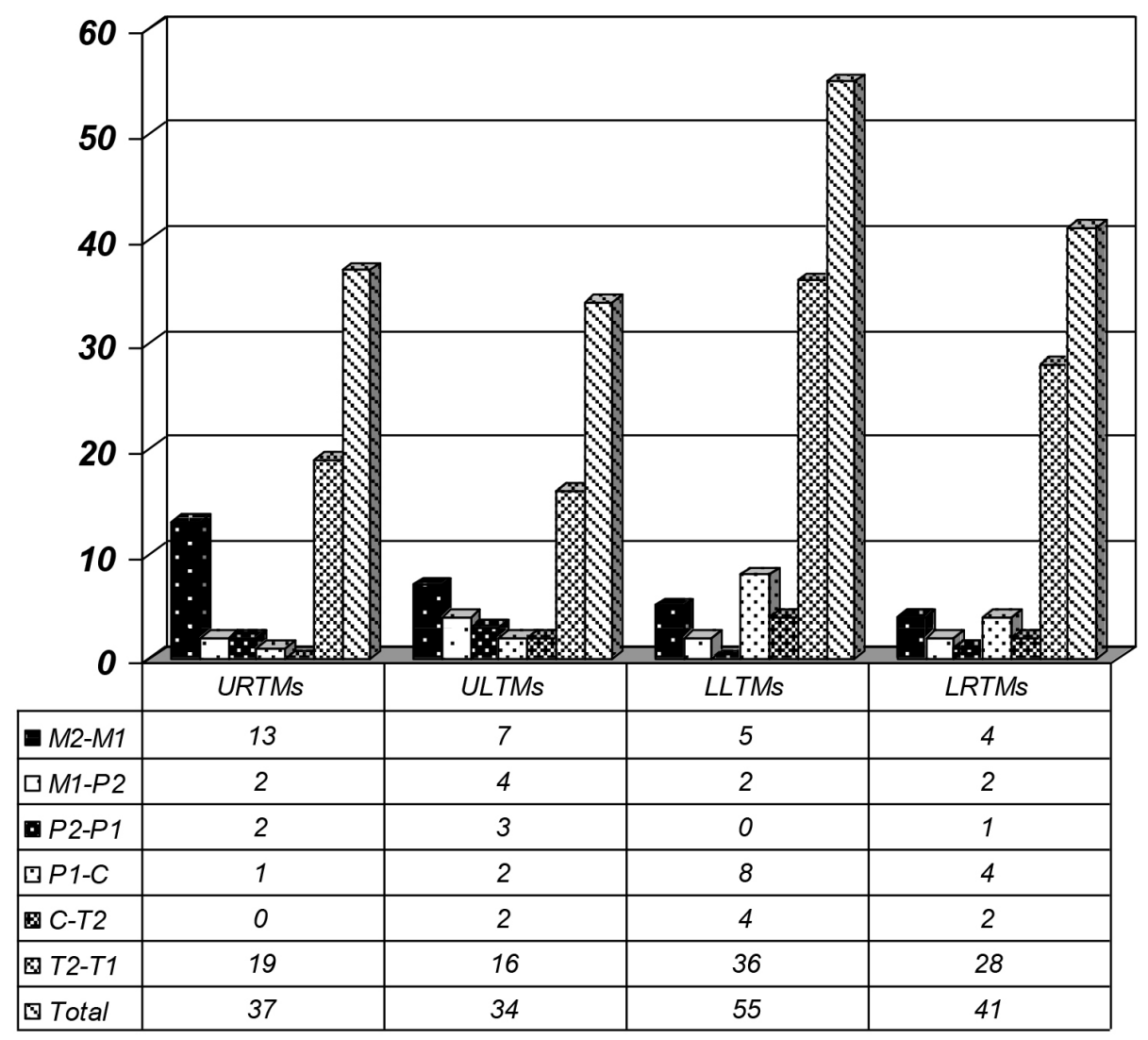

Figure 2. Distribution of root proximities (RP) in interdental spaces for group A.

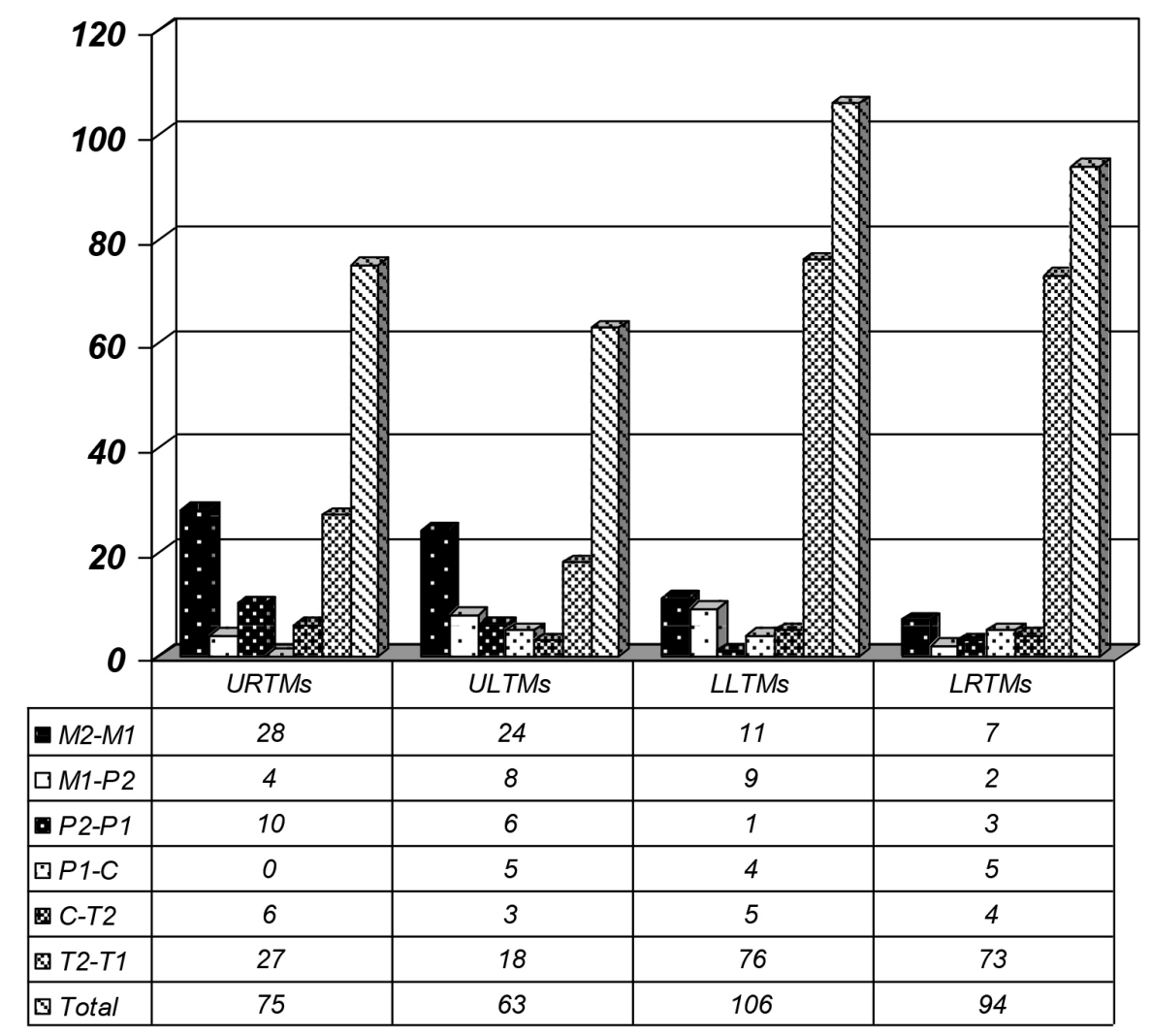

Figure 3. Distribution of root proximities (RP) in interdental spaces for group B. 
The relation between factors concerning the TM, specifically the eruption level, impaction status and angulation, and the presence of $\mathrm{RP}$ in the same quadrant was studied for each subject group. For group A, there were statistically significant differences in TM eruption or impaction status and angulation between the mandibular right M2M1 interdental spaces presenting RP and those non-presenting RP as well as there were statistically significant differences in TM angulation between the mandibular left M2-M1 spaces presenting RP and those non-presenting RP (Table 4). For group B, there were statistically significant differences in TM angulation between the maxillary left $\mathrm{M}_{2}$ $M_{1}$ spaces presenting RP and those non-presenting RP as well as there were statistically significant differences in TM eruption or impaction level between the mandibular right $\mathrm{M}_{2}-\mathrm{M}_{1}$ spaces presenting $R P$ and those non-presenting $\mathrm{RP}$ and the mandibular right $\mathrm{P}_{2}-\mathrm{P}_{1}$ spaces presenting RP and those non-presenting RP (Table 5).

Concerning group A, for both right and left mandibular M2-M1 spaces, the mean value of TM angulation was greater for sites with RP than without RP (LLTMs: $38.6^{\circ} \pm 12.8^{\circ}$ and $12.6^{\circ} \pm 2.2^{\circ}$, respectively, LRTMs: $26.8^{\circ} \pm 9.2^{\circ}, 13.7^{\circ} \pm 2.5^{\circ}$ ) (Figure 4). For group B, whenever there was statistical significance in the TM angulation between sites with or without RP, the mean value of TM angulation was greater for sites with RP than without RP $\left(\mathrm{M}_{2}-\mathrm{M}_{1}\right.$ space/ ULTMs: $19.3^{\circ} \pm 14.8^{\circ}$ versus $10.3^{\circ} \pm 9.1^{\circ}, \mathrm{P}_{2}-\mathrm{P}_{1}$ space/ LRTMs: $16.4^{\circ} \pm 16.8^{\circ}$ versus $4.0^{\circ} \pm$ $1.0^{\circ}$ ) (Figure 4).

Table 4. Comparison of the presence of root proximity in the inetrdental spaces $\left(\mathrm{M}_{2}-\mathrm{M}_{1}, \mathrm{M}_{1}-\mathrm{P}_{2}, \mathrm{P}_{1}-\mathrm{C}, \mathrm{C}-\mathrm{I}_{2}, \mathrm{I}_{2}-\mathrm{I}_{1}\right)$ in relation to the third molar eruption or impaction status (Fisher's exact test) and comparison of the mean third molar angulation values between interdental spaces with or without root proximity (Mann-Whitney test) for group A.

\begin{tabular}{|c|c|c|c|c|c|c|}
\hline Interdental spaces & $\mathbf{M}_{2}-\mathbf{M}_{1}$ & $\mathbf{M}_{1}-\mathbf{P}_{2}$ & $\mathbf{P}_{2}-\mathbf{P}_{1}$ & $\mathbf{P}_{1}-\mathrm{C}$ & $\mathrm{C}-\mathrm{I}_{2}$ & $\mathbf{I}_{2}-\mathbf{I}_{1}$ \\
\hline \multicolumn{7}{|l|}{ URTMS } \\
\hline Eruption or impaction status, p-value* & 1.00 & 0.24 & 1.00 & 1.00 & -- & 0.94 \\
\hline Angle, p-value ${ }^{* *}$ & 0.10 & -- & -- & 0.11 & -- & 0.61 \\
\hline \multicolumn{7}{|l|}{ ULTMS } \\
\hline Eruption or impaction status, p-value* & 0.21 & 0.71 & 2.24 & 0.33 & 0.42 & 0.14 \\
\hline Angle, p-value ${ }^{* *}$ & 0.39 & 0.48 & 0.12 & 0.92 & -- & 0.08 \\
\hline \multicolumn{7}{|l|}{ LLTMS } \\
\hline Eruption or impaction status, p-value* & 0.09 & 1.00 & -- & 0.67 & 0.85 & 0.29 \\
\hline Angle, p-value ${ }^{* *}$ & 0.02 & -- & -- & 0.32 & 0.69 & 0.62 \\
\hline \multicolumn{7}{|l|}{ LRTMS } \\
\hline Eruption or impaction status, p-value* & 0.03 & 1.00 & 1.00 & 0.06 & 0.33 & 0.77 \\
\hline Angle, p-value ${ }^{* *}$ & 0.03 & -- & -- & 0.33 & -- & 0.09 \\
\hline \multicolumn{7}{|c|}{ 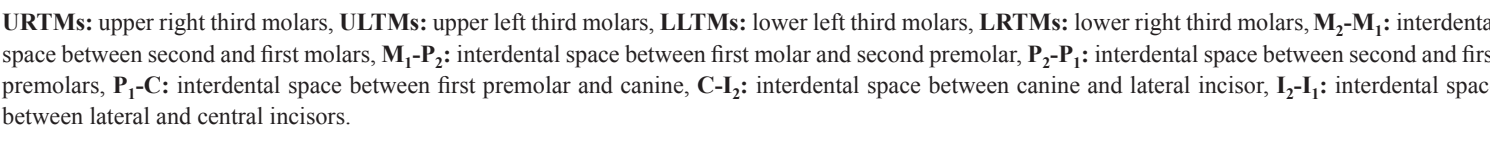 } \\
\hline
\end{tabular}

\section{Discussion}

The present retrospective study was designed to assess the effect of the eruption level or impaction status and angulation of third molars (TMs) on the presence of interdental root proximity (RP) in this quadrant, both in adults with healthy periodontium and in patients with history of periodontitis. In total, $718 \mathrm{TMs}$ and 4,308 interdental spaces were studied in 330 subjects. The results of this study demonstrated that in subjects with healthy periodontium, the angulation of mandibular TMs significantly influenced the presence of root proximity in the interdental space between first and second molars. In periodontitis subjects, TM angulation significantly affected the presence of root proximity in the interdental space between first and second molars in the maxillary left and mandibular right quadrants as well as in the interdental space between the mandibular right premolars. The eruption level or impaction status of TMs significantly affected the presence of root proximity only between the first and second mandibular right molars both for subjects with healthy periodontium and for periodontitis patients. 
Comparing the results of the present study to previous findings is not feasible, since the role of TMs on the presence of RP in the neighboring interdental spaces has not been addressed in the literature yet. However, there are well-documented studies on RP, in which the importance of RP in the presence and progression of periodontitis is investigated $[13,16,17]$. Moreover, there are studies reporting root resorption of second molars in proximity to non-erupted third molars and suggesting the early extraction of impacted third molars, especially in cases with a mesial TM angulation of $60^{\circ}$ or more and an apical TM location in proximity to the distal root of the second molar $[21,22]$. It is widely accepted that one of the main causes for TM impaction, especially for the mandible, is the absence of adequate retromolar space for TM eruption. A limited retromolar space that prevents TM eruption might be implicated in the development of root proximity in the neighboring interdental space. Several factors have been reported to enhance, to a greater or lesser extent, the development of the limited retromolar space. Most of them are related to the time period of development, such as the distal eruption pattern of the teeth, the vertical direction of the condyloid growth which is associated with a decrease in bone resorption of the anterior border of the mandibular ramus, changes in the longitudinal growth of the mandible and delays in the development of facial structures [23, 24]. However, TMs might get erupted later in adult life, after completion of the jaw growth. In such case they often remain partially erupted. It has been claimed that in certain cases TM angulation tends to get reduced with time mainly between 10 and 21 years of age, whereas in other cases TM mesial inclination is increased with time. Orthodontic treatment might increase the retromolar space hoping that this might increase the chances for TM eruption, depending on the initial TM positioning. This seems to have a more favorable effect for the maxillary than the mandibular TMs. The present association between increased TM angulation and RP in the neighboring mandibular molar interdental space in subjects with healthy periodontium might be explained by the forces exerted by the inclined TM in the attempt to erupt.

There are well-established indications for the surgical extraction of impacted TMs [25]. Prophylactic surgical extraction of impacted TMs, which are free of any pathology, has been justified on the basis that TMs do not have important role in the function of the oral cavity, the need to minimize the risk of further disease as cysts and tumors [26] and the risk of mandibular angle fracture $[27,28]$ as well as the increased difficulty of TM surgical extraction with age [26].

Early literature data reported that second molars adjacent to partially or completely erupted TMs, especially in the mandible, were more frequently affected by periodontal disease and were at highest risk to develop periodontitis [29]. Later, it was demonstrated that in case of a visible TM the odds of finding at least one site with periodontal probing depth of $5 \mathrm{~mm}$ or deeper at the adjacent second molar becomes double [30]. Then, it was found that young adults with visible asymptomatic TMs were more likely (almost twice) to have periodontal disease around the adjacent first and second molars than subjects without visible TMs [31]. Moreover, periodontal probing of at least $4 \mathrm{~mm}$ deep was significantly more frequent at proximal molar sites [32] and in case of a visible TM, significantly more sites with clinical attachment loss of at least $3 \mathrm{~mm}$ were detected at the adjacent first and second molars [33]. These finding may partly be explained by the difficulty in successfully removing the dental plaque from the TM area. Plaque accumulation around the TM results in periodontal involvement at the distal surface of the adjacent second molar and may serve as a potential reservoir for oral pathogens colonizing more anteriorly located dental sites [34-36]. It has been suggested that orthodontically-aided extraction of impacted TMs might improve the periodontal condition of the adjacent tooth, though such a treatment plan should be considered only when TM extraction is associated with a high risk of postoperative complications [37]. The presence of root proximity between the third and second molars has been documented as well as the difficulties to control periodontal inflammation at that site $[6,38]$. The present study showed that $25.63 \%$ of the subjects presented agenesis of at least one TM, which was more frequent for the maxilla than the mandible in group A. The prevalence of partially or completely impacted TMs was $19.06 \%$. These findings of TM agenesis are similar to those by Hattab et al. [39] and Rozkovcona et al. [40] but greater than those by Sandhu and Kaur [23] and Celikoglu et al. [2]. These differences might be partly attributed to differences in the age of the subject populations studied, since TM angulation might slightly improve with time up to the age of 24 or 26 years, especially when the initial angulation is $35^{\circ}$ or more [10].

Concluding, within its limits this study found that, the angulation and eruption level or impaction status of third molars seem to be related to interdental root proximity among the adjacent teeth, especially between lower first and second molars, irrespective of the presence or absence of periodontitis.

\section{References}

1. Polder BJ, Van't Hof MA, Van der Linden FP, Kuijpers-Jagtman AM (2004) A meta-analysis of the prevalence of dental agenesis of permanent teeth. Community Dent Oral Epidemiol 32: 217-226. [crossref]

2. Celikoglu M, Miloglu O, Kazanci F (2010) Frequency of agenesis, impaction, angulation, and related pathologic changes of third molar teeth in orthodontic patients. J Oral Maxillofac Surg 68: 990-995. [crossref]

3. Nieminen P (2009) Genetic basis of tooth agenesis. J Exp Zool 312: 320-342. [crossref]

4. Tarazona B, Paredes V, Llamas J-M, Cibrián R, Gandia JL (2010) Influence of first and second premolar extraction or non-extraction treatments on mandibular third molar angulation and position. A comparative study. Med Oral Pathol Oral Cir Bucal 15: 760-766. [crossref]

5. Hattab FN, Alhaija ES (1999) Radiographic evaluation of mandibular third molar eruption space. Oral Surg Oral Med Oral Pathol Oral Radiol Endod 88: 285-291. [crossref]

6. Nance PE, White RP Jr, Offenbacher S, Phillips C, Blakey GH, et al. (2006) Change in third molar angulation and position in young adults and follow-up periodontal pathology. J Oral Maxillofac Surg 64: 424 428. [crossref]

7. Von Wowern N, Nielsen HO (1989) The fate of impacted lower third molars after the age of 20. A four-year clinical follow-up. Int J Oral Maxillofac Surg 18: 277280. [crossref]

8. Ventä I, Murtomaa H, Turtola L, Meurman J, Ylipaavalniemi P (1991) Assessing the eruption of lower third molars on the basis of radiographic features. Br J Oral Maxillofac Surg 29: 259-262. [crossref]

9. Ventä I, Turtola L, Ylipaavalniemi P (1999) Change in clinical status of third molars in adults during 12 years of observation. J Oral Maxillofac Surg 57: 386-389. [crossref]

10. Hattab FN (1997) Positional changes and eruption of impacted mandibular third molars in young adults. A radiographic 4-year follow-up study. Oral Surg Oral Med Oral Pathol Oral Radiol Endod 84: 604-608. [crossref]

11. Kruger E, Thomson WM, Konthasinghe P (2001) Third molar outcomes from age 18-26: findings from a population-based New Zealand longitudinal study. Oral Surg Oral Med Oral Pathol Oral Radiol Endod 92: 150-155. [crossref]

12. Beeman CS (1999) Third molar management: a case for routine removal in adolescent and young adult orthodontic patients. J Oral Maxillofac Surg 57: 824 830. [crossref] 
13. Kim T, Miyamoto T, Nunn ME, Garcia RI, Dietrich T (2008) Root proximity as a risk factor for progression of alveolar bone loss: the veterans affairs dental longitudinal study. J Periodontol 79: 654-659. [crossref]

14. Armitage GC (1999) Development of a classification system for periodontal diseases and conditions. Ann Periodontol 4: 1-6. [crossref]

15. Artun J, Osterberg SK, Kokich VG (1986) Long-term effect of thin interdental alveolar bone on periodontal health after orthodontic treatment. J Periodontol 57: 341-346. [crossref]

16. Vermylen K, De Quincey GN, van’t Hof MA, Wolffe GN, Renggli HH (2005a) Classification, reproducibility and prevalence of root proximity in periodontal patients. J Clin Periodont 32: 254-259. [crossref]

17. Vermylen K, De Quincey GN, Wolffe GN, van 't Hof MA, Renggli HH (2005) Root proximity as a risk marker for periodontal disease: a case-control study. J Clin Periodontol 32: 260-265. [crossref]

18. Van der Sanden WJ, Mettes DG, Plasschaert AJ, Grol RP, van't Hof MA, et al. (2002) Effect of selected literature on dentists' decisions to remove asympomatic, impacted lower third molars. Eur J Oral Sci 110: 2-7. [crossref]

19. Van der Sanden WJ, Mettes DG, Plasschaert AJ, Grol RP, Mulder J, et al. (2005) Effectiveness of clinical practice guideline implementation on lower third molar management in improving clinical decision-making: a randomized controlled trial. Eur J Oral Sci 113: 349-354. [crossref]

20. Hugoson A, Kugelberg CF (1988) The prevalence of third molars in a Swedish population, an epidemiologic study. Community Dent Health 5: 121-128. [crossref]

21. Nemcovsky CE, Libfeld H, Zubery Y (1996) Effect of non-erupted 3rd molars on distal roots and supporting structures of approximal teeth. A radiographic survey of 202 cases. J Clin Periodontol 23: 810-815. [crossref]

22. Nemcovsky CE, Tal H, Pitaru S (1997) Effect of non-erupted third molars on roots of approximal teeth. A radiographic, clinical and histologic study. J Oral Pathol Med 26: 464-469. [crossref]

23. Sandhu S, Kaur T (2005) Radiographic evaluation of the status of third molars in the Asian-Indian students. J Oral Maxillofac Surg 63: 640-645. [crossref]

24. Ay S, Agar U, Biçakçi AA, Köşger HH (2006) Changes in mandibular third molar angle and position after unilateral mandibular first molar extraction. Am J Orthod Dentofacial Orthop 129: 36-41. [crossref]

25. Adeyemo WL (2006) Do pathologies associated with impacted lower third molars justify prophylactic removal? A critical review of the literature. Oral Surg Oral Med Oral Pathol Oral Radiol Endod 102: 448-452. [crossref]

26. Baykul T, Saglam AA, Aydin U, Basak K (2005) Incidence of cystic changes in radiologically normal impacted lower third molar follicles. Oral Surg Oral Med Oral Pathol Oral Radiol Endod 99: 542-545. [crossref]

27. Hanson BP, Cummings P, Rivara FP, John MT (2004) The association of third molars with mandibular angle fractures: a meta-analysis. J Can Dent Assoc 70: 39-43. [crossref]

28. Iida S, Nomura K, Okura M, Kogo M (2004) Influence of the incompletely erupted lower third molar on mandibular angle and condylar fractures. $J$ Trauma 57: 613 617. [crossref]

29. Ash MM, Costich ER, Hayward JR (1962) A study of periodontal hazards of third molars. J Periodontol 33: 209-213.

30. Elter JR, Cuomo C, Offenbacher S, White RP Jr (2004) Third molars associated with periodontal pathology in the Third National Health and Nutrition Examination Survey. J Oral Maxillofac Surg 62: 440-445. [crossref]

31. Blakey GH, Gelesko S, Marciani RD, Haug RH, Offenbacher S, et al. (2010) Third molars and periodontal pathology in American adolescents and young adults: a prevalence study. J Oral Maxillofac Surg 68: 325-329. [crossref]

32. Moss KL, Serio AD, Offenbacher S, Beck JD, Mauriello SM, et al. (2007) The oral and systemic impact of third molar periodontal pathology. J Oral Maxillofac Surg 65: 1739-1745. [crossref]

33. Moss KL, Oh ES, Fisher E, Beck JD, Offenbacher S, et al. (2009) Third molars and periodontal pathologic findings in middle-age and older Americans. J Oral Maxillofac Surg 67: 2592-2598. [crossref]

34. Blakey GH, Jacks MT, Offenbacher S, Nance PE, Phillips C, et al. (2006) Progression of periodontal disease in the second/third molar region in patients with asymptomatic third molars. J Oral Maxillofac Surg 64: 189-193. [crossref]

35. White RP Jr, Offenbacher S, Blakey GH, Haug RH, Jacks MT, et al. (2006) Chronic oral inflammation and the progression of periodontal pathology in the third molar region. J Oral Maxillofac Surg 64: 880-885. [crossref]

36. Moss KL, Serio AD, Offenbacher S, et al Beck JD, White RP Jr (2008) Third molars and the efficacy of mechanical debridement in reducing pathogen levels in pregnant subjects: a pilot study. J Oral Maxillofac Surg 66: 1565-1569. [crossref]

37. Güven O, Keskin A, Akal UK (2000) The incidence of cysts and tumors around impacted third molars. Int J Oral Maxillofac Surg 29: 131-135. [crossref]

38. Akarsian ZZ, Kocabay C (2009) Assessment of the associated symptoms, pathologies, positions and angulations of bilateral occurring mandibular third molars: is there any similarly?. Oral Surg Oral Med Oral Pathol Oral Radiol Endod 108: 26-32. [crossref]

39. Hattab FN, Rawashdeh MA, Fahmy MS (1995) Impaction status of third molars in Jordanian students. Oral Surg Oral Med Oral Pathol Oral Radiol Endod 79: 24-29. [crossref]

40. Rozkovcová E, Marková M, Lánik J, Zvárová J (2004) Agenesis of third molars in young Czech population. Plaque Med Rep 105: 35-52. [crossref]

\section{Citation:}

Loukideli MA, Tsami A, Pepelassi E, Vrotsos I (2019) The effect of eruption level and angulation of third molars on interdental root proximity: A casecontrol study. J Dent Maxillofacial Res Volume 2(1): 1-9. 